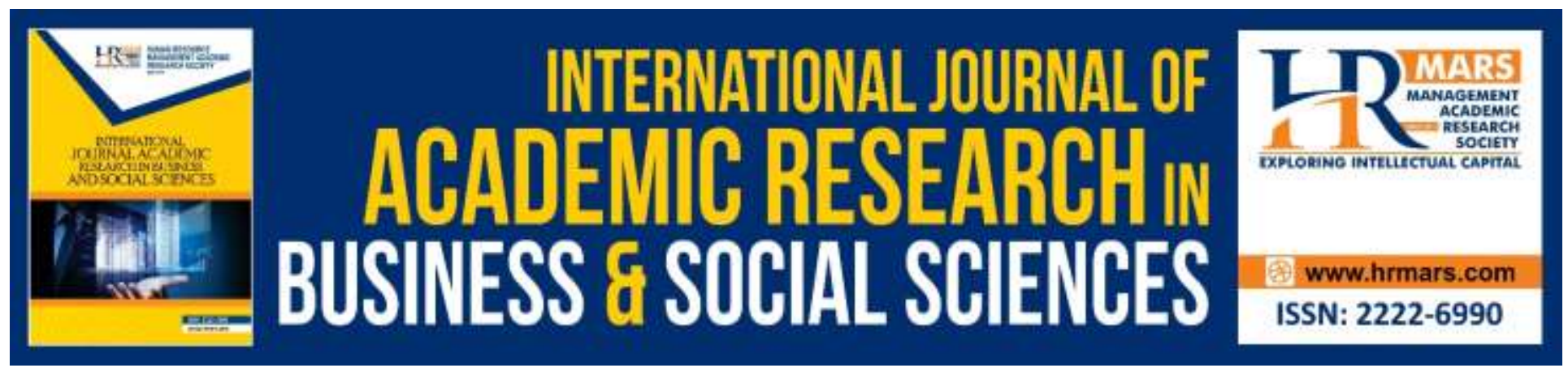

\title{
Intention towards Business Start-Up among Orang Asli in Peninsular Malaysia
}

Siti Asma' Mohd Rosdi, Ahmad Amri Zainal Adnan, Norsamsinar Samsudin

To Link this Article: http://dx.doi.org/10.6007/IJARBSS/v8-i5/4235

DOI:10.6007/IJARBSS/v8-i5/4235

Received: 30 March 2018, Revised: 17 April 2018, Accepted: 29 April 2018

Published Online: 18 May 2018

In-Text Citation: (Rosdi, Adnan, \& Samsudin, 2018)

To Cite this Article: Rosdi, S. A. M., Adnan, A. A. Z., \& Samsudin, N. (2018). Intention towards Business Start-Up among Orang Asli in Peninsular Malaysia. International Journal of Academic Research in Business and Social Sciences, 8(5), 932-945.

Copyright: (C) 2018 The Author(s)

Published by Human Resource Management Academic Research Society (www.hrmars.com)

This article is published under the Creative Commons Attribution (CC BY 4.0) license. Anyone may reproduce, distribute, translate and create derivative works of this article (for both commercial and non-commercial purposes), subject to full attribution to the original publication and authors. The full terms of this license may be seen at: $\underline{\text { http://creativecommons.org/licences/by/4.0/legalcode }}$

Vol. 8, No. 5, May 2018, Pg. 932 - 945

http://hrmars.com/index.php/pages/detail/IJARBSS

JOURNAL HOMEPAGE

Full Terms \& Conditions of access and use can be found at http://hrmars.com/index.php/pages/detail/publication-ethics 


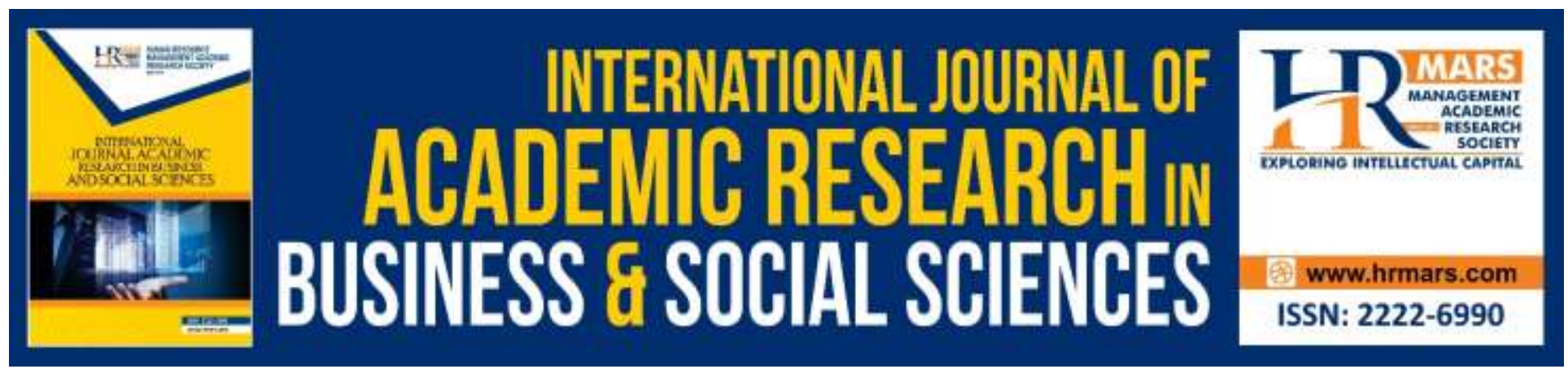

\title{
Intention towards Business Start-Up among Orang Asli in Peninsular Malaysia
}

\author{
Siti Asma' Mohd Rosdi, Ahmad Amri Zainal Adnan, Norsamsinar \\ Samsudin \\ Universiti Pendidikan Sultan Idris, Malaysia
}

\begin{abstract}
Understanding intention is indispensable because it provides an interpretive matrix for precisely deciding an individual action. In business start-up setting, theorist describes an intention as the cognitive representation of a person's readiness to perform a given behaviour.

The purpose of this study is to examine the intention of Orang Asli toward business start-up and their needs in supporting them to start-up business. This paper employs qualitative data that come from focus group interviews with 20 female Orang Asli Semai in Perak State. The findings of this study showed majority of respondents have intention toward business start-up. However, the respondents need some sort of financial and non-financial support to start their business. The case study brings attention to the importance of the intention and entrepreneurship support in order to empower Orang Asli and involve in entrepreneurship activities.
\end{abstract}

Keywords: Intention, Business Start-Up, Entrepreneurship Support, Orang Asli, Malaysia

\section{Introduction}

The significant of business start-up has been well-recognized as creating dynamic entrepreneurship ecosystem. Business and entrepreneurship seems the popular approach to empower the socio-economic development either in rural or in urban setting. Studies on intention to start-up business are not new as it is begin in 1975 by Shapero and he was focused on desirability and personal feasibility. Intention to start-up business which usually derived from a planned decision, before establishing a business is important, as a starting point of new business creation (Neneh, 2014). According to Ajzen (2001), intention comprises four different elements, namely: 'the behaviour'; 'the target', i.e., object at which the behaviour is directed; 'the situation' in which the behaviour is to be performed and 'the time' at which the behaviour is to be performed. According to Allport (1935), the constructs of intention are cognitive, affective and conative; which corresponds to feasibility, desirability, and the intent to act. Linan (2008) concur that the intention is divided into four aspects, namely: i) the aspect as an intermediary to motivational factors that have an impact on behaviour; ii) the aspect of how hard 
someone dares to try; iii) the aspect of how much effort a person planned to do; and iv) the aspect of the close relation to behave further.

In shedding further light on the importance of intention toward business start-up, Krueger, Kickul, Gundry, Wilson and Verma (2009) examined the key attributes of intended new ventures and found that intentions reflect financial performance, environmental performance and behavioural performance. Indeed, intention performs a behavioural conduct are conceptualised as the most immediate and important predictors of behavioural performance (e.g. Ajzen \& Fishbein, 1980; Sheeran \& Orbell, 1999). Behavioural intentions are a summary of people's motivation to perform behaviour. Intentions indicate to what extent people will perform the behaviour and how much effort will be undertaken (Ajzen, 1991). Thus, the intention to business start-up would be a necessary precursor to performing entrepreneurial behaviour (Ajzen \& Fishbein, 1980; Krueger, 2009; Baron, 2004; Shaver \& Scott, 1991). As stated Krueger et al. (2009, p.53), "the construct of intention is appeared to be deeply fundamental to human decision making and, as such, it should afford us multiple fruitful opportunities to explore the connection between intention and a vast array of other theories and model that relate to decision making under risk and uncertainty". According to Krueger and Day (2010), in some cases, the intention is formed shortly before the actual. This was agreed by few scholars (e.g., Van Gelderen et al., 2008; Chattopadhyay \& Ghosh, 2008) that intention as a strong predictor of the decision and a choice to become an entrepreneur.

Studies on intention to start-up business are actually derived from entrepreneurial intention field. Entrepreneurial intention is defined as the decision to start a new business which was planned beforehand and preceded by an objective to accomplish it (Linan \& Chen, 2009; Engle, Dimitriadi, Gavidia, \& Schlaegel, 2010). Entrepreneurial intention is the best approach to encourage an individual to become an entrepreneur (Turker \& Selcuk, 2008; Devonish, Alleyne, Soverall, Marshall \& Pounder, 2009; Engle et al., 2010; Fitzsimmons \& Douglas, 2011). Previous studies show that most of entrepreneurial intention was studied on academic setting (e.g. Gelaidan \& Abdullateef, 2017; Shamsudin, Al Mamun, Nawi, Nasir, \& Zakaria, 2017; Yusoff, Ahmad \& Halim, 2016; Mohamad, Lim, Yusof, Soon, 2015; Arinah, 2015; Afiqah, 2015). Meanwhile, studies on entrepreneurial intention towards non-academic setting (e.g. Choo \& Wong, 2011; Wang, 2009; Zaihana, 2014; Razak, 2009) are limited in numbers especially on rural community setting (Asma, 2016); and (Tateh, 2013).

However, studies on entrepreneurial intention among Orang Asli are still rare. Thus, this study examines the intention of Orang Asli toward business start-up and their needs in supporting them to start-up business. According to Luger and Koo (2005) there are three criterion used in literature to defining start-up business which is "new," "active" and "independent." By using these criterion, the business is considered a start-up when the firm should be not only newly created and active but also independent. The debated on strict definition of new business startup (by using these 3 criterions) raises an important question in conducting research on start-ups, should start-ups, home-based business, online business, spin off and symbiosis be distinguished?. A long debated and arguing by scholars never end as there is no standard definition of business 
INTERNATIONAL JOURNAL OF ACADEMIC RESEARCH IN BUSINESS AND SOCIAL SCIENCES

Vol. 8, No. 5, May 2018, E-ISSN: 2222-6990 @ 2018 HRMARS

start-up firm; thus, this study considers business start-up as newly registered business and active, it is own by respondent.

\section{Orang Asli, Entrepreneurship and Business Start-up in Peninsular Malaysia}

Orang Asli is a group of indigenous peoples who live in Peninsular Malaysia except in Perlis and Pulau Pinang (Ali, 2008). The majority of Orang Asli communities live are in Pahang, followed by Perak and Selangor (Hasril, 2014). Orang Asli is divided into several criteria such as language, culture, way of life and physical characteristics (Ratos, 1932; Norasmah \& Hasril, 2010). Based on these criteria, the Orang Asli of Peninsular Malaysia was divided into three main groups, namely Negrito, Senoi and Proto Malays (Ratos, 1932), and from the three main groups were classified into eighteen minor ethnic groups (Fauzi \& Aini, 2009). In order to strengthening Orang Asli communities, various strategies and approaches in terms of economic, social, educational, human capital, health, and developmental aspects at local and international level has been given serious attention. For example, Jabatan Kemajuan Orang Asli (JAKOA) has been developed to achieve the objective of raising income, expanding social infrastructure and amenities, a higher level of well-being, in the hope that it will produce a new generation of educated and dynamic. Undoubtedly, the role of Orang Asli in the entrepreneurship ecosystem in our country is very important even though the Orang Asli community is a minority of people in Malaysia.

As we known that entrepreneurship can be seen not only as wealth creation platform, but also as human capital development. Entrepreneurship is widely recognised as the engine of economic, social and community development (Edelman, Brush, Manolova \& Greene, 2010). It has also been proved that the Orang Asli have played a significant role in the Malay Peninsula's economic history as collectors and primary traders as early as the 5th Century CE (Ratos, 1932). "Orang Asli became the main suppliers of jungle, river and swamp produce to Malay traders bartered the goods from the Orang Asli to Chinese traders....along the Straits of Malacca" (Ratos, 1932, p.87). Decades of decades, and so on today, the Orang Asli economic sector is highly dependent on geographical position such as landforms and natural resources. Agricultural activity becomes an economic source among Orang Asli communities. The Orang Asli looking for livelihood by selling forest products such as rattan, wood and dammar. These forest products will be sold to the buyers who come or sell on demand. They are looking for these forest produce as well as if there are any interested parties to get it. This shows that the Orang Asli community is exposed to business as one of the main sources of income. However, most of Orang Asli work in vegetable farms belongs to Chinese farmers by joint venturing with Indians, Nepalese and Bangladesh, and they work only for self-sufficiency purposes not for future storage purposes (Norasmah \& Mohd Hasril, 2010; JAKOA 2016). Table 1 shows statistics of Orang Asli who have become entrepreneurs. Based on Jabatan Kemajuan Orang Asli (JAKOA, 2016), the number of Orang Asli entrepreneurs was 534 in 2016 comprising six states in Peninsular Malaysia including Perak, Pahang, Selangor, Negeri Sembilan, Kelantan and Johor.

Table 1.: Entrepreneurs among Orang Asli in Peninsular Malaysia (JAKOA, 2016)

\begin{tabular}{|l|c|c|c|c|c|c|c|}
\hline State/Gender & Johor & Kelantan & N.Sembilan & Pahang & Perak & Selangor & Total \\
\hline Male & 51 & 40 & 24 & 122 & 55 & 43 & 534 \\
\hline Female & 33 & 10 & 27 & 82 & 11 & 36 & 335 \\
\hline Total & 84 & 50 & 51 & 204 & 66 & 79 & 199 \\
\hline
\end{tabular}


The total number of entrepreneurs is 534 considered low. Previous studies show that the involvement of Orang Asli in the productive economy is still low. They rely heavily on forest resources and if they work in other sectors, they are tied to low employment (Fauzi \& Aini, 2009). They argue that it is difficult to carry out economic activities outside their community group. In fact, it is not surprising that studies on entrepreneurial intentions are still rare in the Orang Asli community. According to JAKOA, some of the Orang Asli community attended a vocational training / skill training program conducted by JAKOA. Among the skills courses given are automotive, sewing, agriculture, and handicraft and so on. Meanwhile, from the point of entrepreneurship, not many of them have attended entrepreneurship training. Among the factors that impeded them to venture into business are the constraints of capital and the lack of knowledge to start a business (JAKOA, 2017). Therefore, entrepreneurship programs and training need to be improved and refined to be adapted by Orang Asli communities, with special mentors and educators so that Orang Asli feel closer to a comprehensive and competitive entrepreneurial activity.

\section{Methodology}

Miles and Huberman (1994) used a qualitative approach based on words rather than numbers to obtain a holistic picture that would be rich in understanding. Darke and Shanks (1997) suggests that single case studies are more suitable when cases are unique or extreme. Further, as Benbasat, Goldstein and Mead (1987) found, case study allows the study of a phenomenon of interest in its natural setting. The sample has been defined as a representative of population units studied (Scandura \& Williams, 2000). In this case, the intention towards business start-up were not generalized or understood using results from a survey, but rather explored and understood in the context of attitude towards business start-up. A case study approach seems to be appropriate since this paper is an exploratory study that aims to develop a better understanding of the intention towards business start-up.

This research chose the Orang Asli in rural area based on this reasons. Current literature significantly indicated the limited, readily available information on intention to start-up business in rural community context especially among Orang Asli. Rural community context is chosen based on the spill over effects to the rural community in terms of employment and business opportunities. The Orang Asli who living in rural area has been chosen as respondents based argument by McElwee and Smith, (2014) that rural community is a group of people that have enormous potentials to develop as an entrepreneur. Moreover, the requirement of the discipline's on community research, notably a call to investigate the nature of individual differences from cognitive psychological on the entrepreneurial process and intention-behaviour link.

\section{Data Collection Procedure}

This study utilised qualitative method in the form of focus group interviews. The interviews were conducted in February 2018. The interviews were conducted in Malay language. All interviews were recorded and transcribed verbatim in English by a professional transcriptionist. We sought voluntary participation in the focus group interview and assured the respondents of confidentiality. Focus group interviews were administered on the same day. We operationalised 
our inquiry by asking the participants open questions about their intention to start the business, as well as their assessment on the needs toward start-up business. Consent was obtained from respondents to record the interview. All of the questions were open-ended. The interviews lasted for an hour on average. The interview questions were structured as follows to cover two main areas; intention to start-up business and the needs in supporting them to start-up business:

1. Do you have intention to start-up business?

2. What will you do to start-up business?

3. What business does you intent to start?

4. What kind of support do you need to start-up your business?

\section{Data Analysis}

A qualitative thematic strategy was used to analyze and make sense of the data (Boyatzis, 1998). The data was coded with respect to different formats (interviews, documents), then used constant comparative method to identify major themes (Glaser \& Strauss, 1967). Through constant comparison, the subthemes were identified under each major theme as properties or descriptors to reveal the underlying nature of the themes. The data were presented thematically and the relationship between the findings and current literature was integrated into the discussion of themes (Glaser \& Strauss, 1967).

\section{Results}

Table 2 below summarizes the respondent's demographic profile. All respondents were Orang Asli from Semai tribes with total of 20 female respondents (100\%). Regarding education level, most of them only finished primary school comprises $75 \%(\mathrm{~N}=15)$ and $15 \%(\mathrm{~N}=5)$ completed Sijil Pelajaran Malaysia (SPM). None of respondents completed tertiary education at Diploma or Degree level. In term of marital status, $85 \%(\mathrm{~N}=17)$ of respondents are married, and $15 \%(\mathrm{~N}=3)$ are still single. Based on occupation, most of respondents were housewife comprise $50 \%(\mathrm{~N}=10)$ of respondents, $35 \%(\mathrm{~N}=7)$ of them was working in private sector as cleaner and only $15 \%(\mathrm{~N}=3)$ of them was self-employed.

Table 2: Respondent's Demographic Profile

\begin{tabular}{|l|l|c|c|}
\hline \multicolumn{2}{|c|}{ Demographic } & Frequency (N) & Percentage (\%) \\
\hline Gender & Female & 20 & 100 \\
& Male & 0 & 0 \\
\hline Education level & Diploma/Degree & 0 & 0 \\
& SPM & 5 & 25 \\
& PMR & 0 & 0 \\
& UPSR & 15 & 75 \\
\hline Marital Status & Married & 17 & 85 \\
& Single & 3 & 15 \\
\hline Occupation & Housewife & 10 & 50 \\
& Private sector & 7 & 35 \\
& Public sector & 0 & 0 \\
& Self-employed & 3 & 15 \\
\hline
\end{tabular}


INTERNATIONAL JOURNAL OF ACADEMIC RESEARCH IN BUSINESS AND SOCIAL SCIENCES

Vol. 8, No. 5, May 2018, E-ISSN: 2222-6990 (C) 2018 HRMARS

The results of the focus group interviews are presented in table 3 below guided by four research questions.

Table 3: Findings of the interview

\begin{tabular}{|c|c|}
\hline Themes & Findings \\
\hline $\begin{array}{l}\text { Theme 1: } \\
\text { Intention toward } \\
\text { business start-up }\end{array}$ & $\begin{array}{l}\text { First theme is considering the intention to start business, the effort or } \\
\text { planning to start-up business and the type of product/service that they } \\
\text { intent to start. Based on the results of the interview, majority of the } \\
\text { respondents agreed that they have intention to start-up their own } \\
\text { business. Some of respondents have intention to start-up business if } \\
\text { they will give financial assistance and training. Some of their response } \\
\text { were recorded as below: } \\
\text { "We are intent to start-up business but, we don't know to start". } \\
\text { "Before this, actually, I have been selling burger, but I don't have } \\
\text { enough money to run my business, so I stop it. One day, if I have } \\
\text { money, I want to start it again" } \\
\text { "I have intention to start-up business, but I need support from family } \\
\text { and friends" } \\
\text { "I saw my friends have their own business, so I felt to have my own } \\
\text { business too, but I don't know how to run" } \\
\text { "Then, when researchers asked them on what they will do to start-up } \\
\text { business. We found that: } \\
\text { "I am ready to do anything to start-up business, but I need financial } \\
\text { implies more advantages than disadvantages to me" } \\
\text { "I hap the opportunity and resources, I'd like to start a business" }\end{array}$ \\
\hline
\end{tabular}




\begin{tabular}{|c|c|}
\hline & $\begin{array}{l}\text { Researchers found that most of respondents intent to start-up } \\
\text { business on food product. By asking this question, what business does } \\
\text { you intent to start? Some of their responds were recorded as below: } \\
\text { "I intent to start Cendol and Air Batu Campur (ABC) stall" } \\
\text { "I intent to sell Snack and Laksa" } \\
\text { "I intent to have my own Burger stall" } \\
\text { "I intent to start sewing shop at my home" } \\
\text { "I would like to sell handicraft because my husband and I can skilled on } \\
\text { making handicraft" } \\
\text { "I prefer to have my own Grocery Store, I can start at my house first" } \\
\text { "I think, people in this village would like us to sell food and beverage } \\
\text { so I think, I would like to sell food like Nasi Lemak and Bread" }\end{array}$ \\
\hline $\begin{array}{c}\text { Theme 2: } \\
\text { Supports and } \\
\text { assistances }\end{array}$ & $\begin{array}{l}\text { The respondents sincerely expressed their opinions on the support } \\
\text { that they need, such as network, mentoring program or consultancy } \\
\text { that could train them in aspects of management and marketing. Some } \\
\text { of their responds were recorded as below: } \\
\text { "I need financial assistance to start-up my business" } \\
\text { "I need mentors to guide me on business start-up and manage it". } \\
\text { "I need training and more knowledge on finance and marketing." } \\
\text { "I need training on management." } \\
\text { "I want support from my family and friends to start my business" } \\
\text { "It is not easy to start business because I am no ideas and knowledge } \\
\text { to do that" } \\
\text { "We know business can help us to have more income, but we do not } \\
\text { know how to do, that why we need training and mentor" }\end{array}$ \\
\hline
\end{tabular}

\section{Discussion}

Based on qualitative data, the present study identifies the intention of Orang Asli to start-up business and their needs to do so. Since the respondents were female and living at rural area 
with little facilities to start-up business, this study reveals the fact that the importance of financial and non-financial support is urgently needed by the Orang Asli to start-up business because they have the intention and dreams to do so. They will start-up their own business if they have enough resource, facilities and knowledge. All of respondents were female and majority of respondents are housewives and they are not usually involve in business activities. Although they have set their intention and dreams to start-up their businesses someday, there are some constraints on know-how strategy that cause them not to take action to start a business. The importance assessment of entrepreneurial support is critical today especially to Orang Asli. Supported study found that entrepreneurial support is essential to small business start-up success (e.g. Petridou, \& Glaveli, 2008).

A study conducted by Fauzi and Aini (2009) found that the importance of education towards Orang Asli can determine their quality of life. According to him, the quality of life of the Orang Asli is low when they are uneducated compared to those who are educated. Even though some of them working as self-employed, they are working as an unskilled laborer. Hence, the need for non-financial support such as education and skills needs to be enhanced such as communication skills; information management skills; financial management skills and business management skills. According to Waters, McCabe and Kiellerup (2002) suggest that mentoring is a useful initiative when starting up a new business. Most of them are still inclined to work alone and become full-time housewives. Therefore, they need to be supported by an approach that can add value to them. For example, there are respondents who want to open a sewing shop, handicraft shop, and retail store; their home space can be renovated into a tailor-made shop, handicraft and grocery store with attractive decor. In addition, for those who intend to open food outlets such as Laksa, Cendol, Burger and Snacks stores, they can also find customers online and just make the food products in their own home. Hence, education and training on business management are essential to them so they are confident of starting a business and being independent to continue to compete in the business.

In terms of financial support, many government agencies provide financial support to potential entrepreneurs to start businesses such as TEKUN, Amanah Ikhtiar Malaysia (AIM), SME Corp and so on. There are also various loan schemes offered such as the Micro Credit Loan Scheme, and the Village Economy Financing Scheme, Interest-Free Loan Scheme and various loan schemes offered by local banks. However, the majority of respondents do not know about the existence of the scheme. In fact there are respondents who do not want to make loans because they are afraid that they cannot repay the loan. Supported studies shows that only $1 \%$ of the Orang Asli households received non-interest bearing loans. A very small percentage compared to the help provided (Fauzi \& Aini, 2009). Since the Orang Asli live in rural areas and have their own mindset and culture, the approaches to be given must be in line with their way of life so as they not to be neglected and abandoned in productive economics to become successful entrepreneurs someday. Hence the participatory approach is encouraged because this approach emphasizes the joint participation of the Orang Asli itself in every aspect and activity of starting a business. Besides assisting and supporting Orang Asli, they can also adapt their attitudes and mindsets in line with market demands.

Supported studies also suggested that local community in rural area faces challenges and difficulties in starting up a business (OECD, 2005). In Malaysia, the participation of rural residents in entrepreneurship and training programme is still low (Che Abdullah \& Mustapha, 2009; Buang, 
Raduan \& Husin, 2010; Talib \& Jusoh, 2012). Concerns have been voiced regarding this issue and the causes were also highlighted by various parties. For example, the limited capital or financial constraint (Talib \& Jusoh, 2012; Talib, Jusoh, Ibrahim, \& Ahmad, 2012), lack of entrepreneurship mind-set (Rural Development Master Plan, 2010), limited opportunities for entrepreneurial activities (Ahmad, Yusoff, Noor \& Ramin, 2012), land issues, low productivity, low educational level and skills (Yusnita, Shaladdin \& Aziz, 2013) have restricted the local community in rural area to participate in entrepreneurship. Ahmad et al. (2012) highlight that rural community confronts lack of assistance and favourable conducive environment to develop entrepreneurship programmes in comparison to urban settings. Besides that, Yusnita et al. (2013) indicate that communities in rural area are still traditionally performing the farming and livestock activities. As a result, they faced difficulties in starting up the business to develop and survive in their life. In addition, Salleh and Sidek (2011) believe that entrepreneurial attitudes, small size of local markets and social capital are among the most challenges that hinder rural community to involve in business and entrepreneurship. Therefore, financial, training and mentoring support deserve more research attention in countering entrepreneurial challenges and achieving success at the start-up stage of business among Orang Asli. Future researchers may also look into the possible challenges in supporting the Orang Asli to start-up business.

\section{Conclusion}

In summary, the present study offers valuable insights to practitioners, researchers and policy makers. Practically, assessing the intention of Orang Asli to start-up business and by addressing their needs of support, this study contributes to the authorities, as well as to the nations that are striving towards business start-up success play vital roles. Theoretically, this study adds value to the existing literature and to the body of knowledge by bringing up important factors such as financial and non-financial support towards start-up success. These variables deserve more attention to better comprehend start-up success of Orang Asli nascent entrepreneur. The urge for entrepreneur support calls for future researchers to delve into the impact of support on startup success. From a policy perspective, the study revealed a great need for the development of policy instruments which will improve the entrepreneur support system especially to rural communities and Orang Asli.

\section{Acknowledgement}

Sincere thanks to the Universiti Pendidikan Sultan Idris for providing the funding for this project under Geran Pendidikan Universiti (Research Code: 2017-0252-107-01). Special thank goes to Tok Batin and Orang Asli at Kampung Chinggung, Behrang Ulu, Perak, Malaysia for their support and contributions.

\section{Corresponding Author}

Siti Asma' Binti Mohd Rosdi

Senior Lecturer

Universiti Pendidikan Sultan Idris

35900, Tanjung Malim, Perak

Malaysia

Email: sitiasma@fpe.upsi.edu.my 
INTERNATIONAL JOURNAL OF ACADEMIC RESEARCH IN BUSINESS AND SOCIAL SCIENCES

Vol. 8, No. 5, May 2018, E-ISSN: 2222-6990 @ 2018 HRMARS

\section{References}

Afiqah, N. I. (2015) Factors influencing UTeM undergraduate engineering student's intention to be entrepreneurs. Project Report. UTeM, Melaka, Malaysia.

Ahmad, A. R., Yusoff, W. F., Noor, M. H., \& Ramin, A. K. (2012). Preliminary study of rural entrepreneurship development program in Malaysia. Journal of Global Entrepreneurship, 2(1), 1-8.

Ajzen, I. (1991). The theory of planned behaviour. Organizational Behaviour and Human Decision Processes, 50(2), 179-211.

Ajzen, I. (2001). Nature and operation of attitudes. Annual Review of Psychology, 52, $27-58$.

Ajzen, I., \& Fishbein, M. (1980). Understanding attitudes and predicting social behaviour. Englewood Cliffs, NJ: Prentice-Hall.

Ali, Z. A. (2008). "Peranan Jabatan Hal Ehwal Orang Asli (JHEOA) dalam pembangunan masyarakat Orang Asli, In. Marof Redzuan \& Sarjit S. Gill. 2008," Orang Asli: isu, transformasi dan cabaran. Serdang: Universiti Putra Malaysia.

Allport, G. W. (1935). Attitudes. In Murchison, C. (eds.) Handbook of social psychology, pp. 798-884. Worcester, MA: Clark University.

Arinah, S. N. I. (2015). The impact of entrepreneurial education and training on student's entrepreneurial intention. Project Report. UTeM, Melaka, Malaysia.

Asma', S. M. R. (2016). Factors influencing entrepreneurial intention among rural community in Lenggong Valley. Unpublished doctoral dissertation. Universiti Sains Malaysia.

Benbasat, I., Goldstein, D. K., \& Mead, M. (1987). The case research strategy in studies of information systems. MIS Quarterly, 11 (3), 369-386.

Boyatzis, R. (1998). Transforming Qualitative Information: Thematic Analysis and Code Development. Sage: Thousand Oaks, CA.

Buang, N. A., Raduan, I., \& Husin, M. (2010). Kajian impak program pembudayaan keusahawanan. Institut Keusahawanan Negara (2006-2009). Unpublished manuscript, research project, Universiti Kebangsaan Malaysia, Bangi.

Chattopadhyay, R., \& Ghosh, A. K. (2008). Entrepreneurial intention model-based quantitative approach to estimate entrepreneurial success. Journal of Small Business and Entrepreneurship, 21 (1), 1-22.

Che Abdullah, N., \& Mustapha, R. (2009). Kajian kes usahawan tani industri kecil sederhana (IKS) bumiputera di Negeri Terengganu. Jurnal Pendidikan Malaysia, 34(2), 143 - 165.

Choo, S., \& Wong, M. (2011). Entrepreneurial intention: triggers and barriers to new venture creations in Singapore. Singapore Management Review, 28(2), 47-64.

Darke, P., \& Shanks, G. (1997), User viewpoint modelling: understanding and representing using users viewpoints during requirements definition, Information Systems Journal, 7, (3), 213-239.

Devonish., D., Alleyne. P., Charles-Soverall, W., Marshall, A. Y., \& Pounder, P. (2009). Explaining entrepreneurial intentions in the Caribbean. International Journal of Entrepreneurial Behaviour \& Research, 16(2), 149-171. 
Edelman, L. F., Brush, C. G., Manolova, T. S., \& Greene, P. G. (2010). Start-up motivations and growth intentions of minority nascent entrepreneurs. Journal of Small Business Management, 48 (2), 174-196.

Engle., R. L., Dimitriadi, N., Gavidia J. V., \& Schlaegel, C. (2010). Entrepreneurial intent; A twelvecountry evaluation of Ajzen's model of planned behaviour. International Journal of Entrepreneurial Behaviour \& Research, 16 (1), 35.

Fauzi, M. H., \& Aini, N. I. (2009). Pembangunan Masyarakat Orang Asli: Dilema Miskin dan Terpinggir. Selangor: Pusat Penerbitan Universiti.

Fitzsimmons, J. R., \& Douglas, E. J. (2011). Interaction between feasibility and desirability in the formation of entrepreneurial intentions. Journal of Business Venturing, 26, 431440.

Gelaidan, H. M., \& Abdullateef, A. O. (2017). Entrepreneurial intentions of business students in Malaysia: The role of self-confidence, educational and relation support, Journal of Small Business and Enterprise Development, 24(1), 54-67.

Gelderen, V. M., Brand, M., Praag, V. M., Bodewes, W., Poutsma, E., \& Gils, V. A. (2008). Explaining entrepreneurial intentions by means of the theory of planned behaviour. Career Development International, 13(6), 538-559.

Glaser, B., \& Strauss, A. (1967). The Discovery of Grounded Theory: Strategies for Qualitative Research. Aldine: Chicago, IL.

Hasril, M. A. (2014). Keberkesanan modul asas keusahawanan bercirikan strategi pembelajaran masteri terhadap pelajar Orang Asli. PhD Tesis. Universiti Kebangsaan Malaysia.

Jabatan Kemajuan Orang Asli. (JAKOA). (2017). Interview Report.

Krueger, N. F. (2009). Entrepreneurial intentions are dead: Long live entrepreneurial intentions. In A. L. Carsrud, \& M. Brännback (Eds.), Understanding the entrepreneurial mind (pp. 51-72). New York: Springer.

Krueger, N. F., \& Day, M. (2010). Looking forward, looking backward: From entrepreneurial cognition to neuroentrepreneurship. In Acs, Z. J. \& Audretsch, D. B. (Eds.), Handbook of entrepreneurship research. An interdisciplinary survey and introduction, pp. 321-358. (2nd ed.). New York: Springer.

Krueger, N., Kickul, J., Gundry, L., Wilson, F., \& Verma, R. (2009). Discrete choices, trade- offs and advantages: Modeling social venture opportunities and intentions. In: Robinson J, Mair J, Hockerts K (eds.) International Perspectives on Social Entrepreneurship. UK: Palgrave.

Linan, F. (2008). Skill and value perceptions: how do they affect entrepreneurial intentions?. Journal of International Entrepreneurship Management, 4, 257-272.

Linan, F., \& Chen, Y. W. (2009). Development and cross-cultural application of a specific instrument to measure entrepreneurial intentions. Entrepreneurship Theory and Practice. 593-617.

Luger, M. I., \& Koo, J. (2005). Defining and tracking business start-up. Small Business Economics, 24: 17-28.

McElwee, G., \& Smith, R. (2014). Rural entrepreneurship. In A. Fayolle (Ed.), Handbook of research in entrepreneurship. Cheltenham, UK: Edward Elgar.

Miles, M. B., \& Huberman, A. M. (1994). Qualitative Data Analysis. Sage Publications: Thousand Oaks, CA. 
Mohamad, N., Lim, H. E., Yusof, N., \& Soon, J. J. (2015). Estimating the effect of entrepreneur education on graduates' intention to be entrepreneurs", Education + Training, 57 (8/9), 874-890.

Mohamad, Salleh, M., \& Sidek, M. N. Z. (2011). Rural entrepreneurship: A challenges and opportunities of rural micro enterprise (RME) in Malaysia. Interdisciplinary Journal of Contemporary Research in Business, 2(11), 573- 583.

Neneh, B. N. (2014). An assessment of entrepreneurial intention among university students in Cameroon. Mediterranean Journal of Social Sciences, 5(20), 542-552.

Ollince, Tateh, A. (2013) Indigenous entrepreneurship: Entrepreneurial intentions of Dayak youth in Sarawak, Malaysia. Masters thesis, Universiti Malaysia Sarawak.

Othman, N., \& Amiruddin, M. H. (2010). The readiness of the Orang Asli youths in venturing into entrepreneurship, in Proc. 9th WSEAS International Conference on Education and Educational Technology (EDU '10), Iwate Prefectural University, Japan, pp. 235-240.

Petridou, E., \&Glaveli, N. (2008), Rural women entrepreneurship within co-operatives: training support. Gender in Management: An International Journal, 23(4), 262-277.

Ratos, A. (1932). Orang Asli and Their Wood Art. Singapore: Marshall Cavendish Edition.

Ray, D. M. (1993). Understanding the entrepreneur: entrepreneurial attributes, experience and skills. Entrepreneurship and Regional Development: An International Journal, 5(4), 345-358.

Razak, A. N. (2009). Kekuatan Niat Keusahawanan Pelatih Industri Automotif Terhadap Kerjaya Usahawan Era Terkini. Masters Thesis, Universiti Teknologi Malaysia.

Rural Development Master Plan. (2010). Ministry of rural and regional development. Malaysia.

Scandura, T. A., \& Williams, E. A. (2000). Research methodology in management: Current practices, trends and implications for future research. Academy of Management Journal, 43, 1248-1264.

Shamsudin, S. F. F., Al Mamun, A., Nawi, C. N., Nasir, M. N. A., \& Zakaria, M. N. (2017). Factors affecting entrepreneurial intention among the Malaysian university students. The Journal of Developing Areas, 51 (4), 424-431.

Shapero, A. (1975). Who starts new businesses? the displaced, uncomfortable entrepreneur. Psychology Today, 9, 83-88.

Sheeran, P., \& Orbell, S. (1999). Implementation intentions and repeated behaviour: Augmenting the predictive validity of the theory of planned behaviour. European Journal of Social Psychology, 29, 349-369.

Turker, D., \& Selcuk, S. S. (2008). Which factors affect entrepreneurial intention of university students. Journal of European Industrial Training, 33(2), 142-159.

Wang, T. (2009). Distinguishing and linking entrepreneurial intention and action. Unpublished doctoral dissertation. University of Western Ontario. Canada.

Waters, L., McCabe, M., Kiellerup, D., \& Kiellerup, S. (2002). The Role of Formal Mentoring on Business Success and Self-Esteem in Participants of a New Business Start-Up Program. Journal of Business and Psychology, 17 (1), 107-121.

Yusnita, Y., Shaladdin, M. M., \& Aziz, A. (2013). Rural tourism in Malaysia: A homestay program, China-USA Business Review, 12(3), 300-306. 
INTERNATIONAL JOURNAL OF ACADEMIC RESEARCH IN BUSINESS AND SOCIAL SCIENCES

Vol. 8, No. 5, May 2018, E-ISSN: 2222-6990 @ 2018 HRMARS

Yusoff, A., Ahmad, N. H., \& Halim, A. H. (2016). Entrepreneurial orientation and agropreneurial intention among Malaysian agricultural students: the impact of agropreneurship education. Advances in Business-Related Scientific Research Journal, 7 (1), 78-92.

Zaihana, M. (2014) Kajian kecenderungan keusahawanan di kalangan pelatih Pusat Giat Mara Negeri Kedah. Masters Thesis, Universiti Utara Malaysia. 